\title{
Motivation as Contributing Factor That Impacts Teaching Excellence in Learning
}

\author{
Putu Sora Dipa \\ Ganesha University of Education, Bali \\ soradipa10@gmail.com
}

\begin{abstract}
Motivation is known as a dynamic and complex thing that provides an important role in learning related to success and failure. There are many factors that greatly influence the quality of teaching motivation. The quality of teaching will be important in the learning process in various ways in education. Education is an important part of the learning process. Commitment and sincerity are things that should be considered in shaping learning patterns to achieve improvement and change. One of the factors that can influence the learning process is motivation. Teaching motivation is usually influenced by a lot of knowledge and experience from someone so that the topic or information provided can be conveyed properly. This article will explain the various factors that can improve the quality of teaching motivation that influences education and learning.
\end{abstract}

Keywords: Education, Learning, Teaching, Motivation

\section{INTRODUCTION}

Education is important in life to find a variety of useful information for everyone in carrying out activities. Education has always been an important part of the life process by getting values in every lesson that is carried out. In learning, of course, there are various activities that must be carried out in accordance with predetermined processes as learning targets (Iliya \& Ifeoma, 2015). Delivering material is certainly one of the most important things in learning. In delivering material, of course, involves aspects of motivation in teaching. According to Han (2019), teaching motivation is a very big influence in learning in determining success in education. Teaching motivation will stimulate someone to learn in an effort to increase knowledge. Cahyani et al., (2020) stated that teaching motivation is said to be dynamic and very complex and has an important role in every learning situation in terms of success and failure. Motivation is a very complex idea and has a responsibility in determining human behavior by providing it with information. According Falout (2010), teaching motivation can influence various factors in improving the quality of learning to influence someone in learning.

Teaching excellence is a result that will be obtained when motivation in learning is well implemented. According to (Kreber, 2002) teaching excellence can be identified based on an assessment of a person's performance obtained through motivation. An important point in teaching excellence is the prior experience that forms the basis of learning. (Roberts, 2013) stated that teaching excellence is very influential on the success of the learning process which will have a huge impact in obtaining information. The teaching experience of a teacher will have an important 
impact on the learning process of English for students or Teaching English for Young Learners (TEYL) so that students get maximum information from the teacher so that these students can also give maximum results in the learning process.

Motivation in teaching excellence is very necessary in the learning process. Motivation will also make the learning process happen very quickly and pleasantly (Kotherja, 2013). Motivation is very influential in a learning process, especially by teachers when providing learning materials to students (Mustafa, 2009). Motivation will have a good impact on a teacher to be able to provide the best results in the learning process so that it increases to be greater in a learning process.

\section{METHOD}

The method used in data collection is literature study. There are four steps in this research. The first step is to collect data related to this research from primary and secondary sources. The primary source is data obtained from a study of research papers related to the implementation of character education in TEYL (Teaching English for Young Learners). Meanwhile, secondary resources mean collecting data from several articles and related books to support this research. The second step is to classify the data related to teaching motivation and teaching excellence, especially those that are focused on their implementation in the process of learning English for students. The third step is to analyze the data. The results of the research library were analyzed to identify the concept of character education and its implementation in the learning process of English for students. Based on the results of the research library, a conclusion can be drawn which is the last step of this research.

\section{FINDINGS \& DISCUSSIONS}

In the findings and discussion, we will discuss teaching motivation and teaching excellence. Teaching motivation and teaching excellence have a strong relationship in the learning process in schools. Motivation will be very helpful in the learning process to be able to get the most out of a learning process (Utomo, 2018). Teaching excellence here will focus on the teacher who teaches or provides information related to the topic of learning in the learning process for students based on the experiences that the teacher has gained (Barni et al., 2019). The teacher must also always have a maximum impact in every learning process so that the results of the process are maximized (Gilakjani, 2017). Motivation and teaching excellence can have a positive impact in the world of education, especially in learning English to teach students or Teaching English for Young Learners (TEYL).

Teaching motivation is very much influenced by the work environment and training and development is very significant for motivation. In addition, good management can improve the quality of a motivation, so that a sense of concern for obligations arises. Sabiq (2018) stated that motivation is a very complex idea. 
Motivation has a responsibility in determining human behavior by providing it with information. According to Mark, (2015), hierarchy of need theory affects a person's motivation to do something in a learning situation. Boneva (2012), stated that individual motivation appears when the individual has met their basic needs, giving rise to increased working conditions and a positive impact.

According to Mark (2015), motivation-hygiene theory emphasizes the intrinsic and extrinsic factors of a teacher. Gilakjani (2017) stated that these intrinsic and extrinsic factors have an impact that will greatly impact the education that is directly involved with the instructor. The intrinsic factor when a person is only concerned with his personal needs and carries out tasks for himself with satisfaction can be said to be a feeling of self-achievement and self-actualization (Noviyanti, 2018). Meanwhile, extrinsic factor is something that is rewarded such as a salary. Motivation is also influenced by environmental factors because it is not only based on the need for motivation theory alone, the needs of a teacher must be met so that the learning process can be carried out properly and improve in quality. Motivation will affect a teacher in carrying out their duties and motivation can determine the type of coaching that is carried out (Yagcioglu, 2016). Personality factors are also a determinant of teaching motivation which has a close relationship with intrinsic teaching motivation.

Teaching Excellence

According to Kreber (2002), teaching excellence can be identified based on an assessment of a person's performance obtained through motivation. Gilakjani (2017) stated that teaching excellence can be assessed from the performance that has been done in the learning process. Teaching excellence can be assessed from the effective teaching and quality of learning carried out. Awla (2014) states that teachers who have more experience will be very useful in teaching excellence because they are considered useful in conveying material or information. In his research, Kreber (2002) said that teaching excellence is very important in learning to get maximum results based on the process that has been passed. So that teaching excellence is very necessary in the learning process because the teaching excellence has very important aspects such as experience which is very necessary to get maximum results.

These results will be very helpful in developing the level of learning that will greatly impact each individual student in solving problems encountered during the learning process. The teacher as a facilitator in the learning process must have a strong character in teaching to be able to convey learning material based on the experiences that have been obtained so that it can be conveyed to students properly (Awla, 2014). Teachers must also continue to learn to be able to develop innovations in teaching so that students have various ways in the learning process to be able to solve problems and provide maximum results (Hashim et al., 2015)

\section{CONCLUSIONS}

From the research results, it can be concluded that one of the factors that improve the quality of teaching motivation is the intrinsic and extrinsic factors that 
occur in education. This technique will be very helpful in improving the quality of teaching which will affect other people who receive information and can foster the enthusiasm of other people or students in the learning process. By increasing teaching motivation, it is hoped that it can be used optimally in the learning process not only at school but in the social environment, because the social environment also has an influence in improving the quality of teaching motivation. therefore, as teachers we must pay attention to these aspects, so that later we can provide maximum knowledge or information with the abilities and experiences we already have to be able to give to other people or students.

\section{REFERENCES}

Awla, H. A. (2014). Learning Styles and Their Relation to Teaching Styles. International Journal of Language and Linguistics, 2(3), 241. https://doi.org/10.11648/j.jill.20140203.23

Barni, D., Danioni, F., \& Benevene, P. (2019). Teachers' self-efficacy: The role of personal values and motivations for teaching. Frontiers in Psychology, 10(JULY), 1-7. https://doi.org/10.3389/fpsyg.2019.01645

Boneva, D. (2012). Learning Styles and Learning Preferences (8th ed., Vol. 8). Daniela Boneva and Elena Mihova.

Cahyani, A., Listiana, I. D., \& Larasati, S. P. D. (2020). Motivasi Belajar Siswa SMA pada Pembelajaran Daring di Masa Pandemi Covid-19. IQ (IImu AlQur'an): Jurnal Pendidikan Islam, 3(01), 123-140. https://doi.org/10.37542/iq.v3i01.57

Falout, J. (2010). Strategies for teacher motivation. 6(December), 27-32.

Gilakjani, A. P. (2017). Visual , Auditory, Kinaesthetic Learning Styles and Their Impacts on English Language Teaching. June. https://doi.org/10.5296/jse.v2i1.1007

Han, J. (2019). Teacher motivation: Definition, research development and implications for teachers. 1(December 2016), 18. https://doi.org/10.1080/2331186X.2016.1217819

Hashim, A. T., Osman, R., Arifin, A., Abdullah, N., \& Noh, N. M. (2015). Teachers' Perception on Higher Order Thinking Skills as an Innovation and its Implementation in History Teaching. Australian Journal of Basic and Applied Sciences, October, 215-221.

Iliya, A., \& Ifeoma, L. G. (2015). Assessment of Teacher Motivation Approaches in the Less Developed Countries. Journal of Education and Practice, 6(22), $10-18$.

Kotherja, O. (2013). Teachers' motivation importance and Burnout effect in the educational development. 358-365.

Kreber, C. (2002). Teaching Excellence, Teaching Expertise, and the Scholarship of Teaching. 27(1), 5-23.

Mark, A. (2015). Factors Influencing Teachers' Motivation and Job Performance in Kibaha District, Tanzania. 1, 105.

Mustafa, M. N. (2009). Factors that Influence Quality Service of Teachers. Aminuddin 1994, 1994-1999.

Noviyanti, S. D. (2018). Students' Reading Preference and Its Implications: a Study of Three English Education Departments in Jember. Lingua Scientia, 
25(2), 89. https://doi.org/10.23887/ls.v25i2.18826

Roberts, K. J. (2013). A Model for a Center for Teaching and Learning Excellence : A Catalyst for Program Improvement in Developing Institutions. 4, 108-118. https://doi.org/10.5195/ehe.2013.98

Sabiq, A. H. (2018). Improving Students' Motivation and Reading Skills in Elt Through Audio Visual Media. Diksi, 25(1), 57-68. https://doi.org/10.21831/diksi.v25i1.16007

Utomo, H. B. (2018). Teacher Motivation Behavior : The Importance Of Personal Expectations, Need Satisfaction, And Work Climate. International Journal of Pedagogy and Teacher Education (IJPTE), 2(2), 333-342. https://doi.org/10.20961/ijpte.v2i2.24036

Yagcioglu, O. (2016). The Positive Effect of Cognitive Learning Styles. European Journal of English Language Teaching, 1(2), 78-91. 